\title{
EL MÁS LITERATO DE TODOS LOS PERIODISTAS O EL MÁS PERIODISTA DE TODOS LOS LITERATOS: MARIANO DE CAVIA EN EL LIBERAL. LA RETÓRICA ARGUMENTATIVA DE LA SERIE «PLATO DEL DÍA»
}

\author{
PilAR BELLIDO NAVARRO \\ pbellido@us.es \\ Universidad de Sevilla
}

\section{Resumen}

Mariano de Cavia es una de las figuras más destacadas del periodismo literario de fin de siglo. Sin embargo, su obra todavía permanece en el olvido. La dificultad de acceder a una producción tan amplia, dispersa y sujeta a la actualidad ha provocado el desapego de los estudiosos. Con todo, su análisis es indispensable para conocer la evolución de la prosa española durante los siglos XIX y XX.

Dos son los objetivos del presente trabajo: abordar, primero, el estudio de su personalidad, formación y deontología profesional para ubicarlo dentro de la generación «puente» entre el grupo realista y la generación de fin de siglo. Por otra parte, he realizado una primera cala en una de sus series más conocidas, «Plato del día». El análisis de su retórica argumentativa me ha permitido detectar un eslabón importante en la evolución de la prosa decimonónica hacia el siglo XX.

Palabras Clave: Mariano de Cavia, «Plato del día», El Liberal, bohemia, periodismo literario, prosa española, deontología periodística, realismo decimonónico, fin de siglo, retórica, argumentación.

\footnotetext{
Abstract

Mariano de Cavia is one of the leading turn-of-the-century figures in literary journalism. However, his works still remain forgotten. The difficulty of accessing such a huge, dispersed and up-to-date corpus of works has provoked a general disregard amongst scholars. All the same, a thorough analysis of his works is essential to understand the evolution of Spanish prose during the 19th and 20th centuries.
} 
This paper is concerned with two main objectives: first, to address an examination of his personality, education and professional deontology in order to define his position between the realists and the generation of the end of the century. On the other hand, I have made an initial advance concerning one of his most famous headlines, «Plato del día». The examination of its argumentative rhetoric allowed us to recognize an important link in the evolution of 19th century prose towards the 20th century.

Keywords: Mariano de Cavia, «Plato del día», El Liberal, bohemianism, literary journalism, Spanish prose, journalistic deontology, 19th-century realism, turn-of-the-century, rhetoric, argumentation.

Mariano de Cavia es una de las figuras más destacadas de la historia del periodismo literario de fin de siglo. Hasta su muerte, ocurrida el 14 de julio de 1920, fue considerado maestro de periodistas por la calidad de su prosa y su actitud ética entre aquéllos que, más jóvenes que él, lo conocieron y trataron ${ }^{1}$. Sin embargo, resulta sorprendente constatar el olvido en el que se ha sumergido su obra, pues no ha sido objeto de interés frecuente para los estudiosos del periodismo ni de la literatura (Cavia, 2008a: 17-25)2. Tal vez el motivo de tal

1. «El periodismo español ha perdido a su maestro» reza el titular de primera plana de $E l$ Sol del jueves, 15 de julio de 1920. «Te he velado, maestro» es el título del artículo de Félix Lorenzo, cuyo comienzo afirma de nuevo el magisterio de Cavia: «A tu lado estoy, maestro querido, como tantas otras veces». «Hoy reposarán los restos del maestro en tierra aragonesa» es el titular también de primera plana de El Sol del viernes, 16 de julio de 1920. El diario La Voz en el artículo necrológico del 15 de julio de 1920 afirmaba: «Demos al maestro y al amigo un adiós salido del alma. Descubrámonos reverentes. ¡Cavia se fue! Pero mientras haya en el mundo gentes que hablen castellano, el recuerdo del gran escritor, que no quiso ser más que periodista, pudiendo haber sido tantas cosas, vivirá inmarcesible». También La Acción en su necrológica insiste en el mismo aspecto: «El comentario del maestro era siempre una musa sutil, de concepto risueño y armoniosa y ondulante en sus giros, un poco escéptica, con unos leves visos de desengaño; pero en todo momento ágil y exquisita». Idénticos términos de respeto y admiración se repiten en los artículos que a su muerte le dedicaron $A B C$, El Liberal, El Imparcial, Heraldo de Madrid, Hoy, La Tribuna, La Época, La Correspondencia de España, El País, El Socialista, La Libertad, Heraldo de Aragón, El Noticiero de Barcelona, entre otros. Muchos de estos testimonios de dolor fueron recogidos por El Sol, el viernes, 16 julio 1920, pág. 2.

2. En la actualidad, su nombre, al menos, resurge cada año al convocarse y celebrarse el prestigioso premio «Mariano de Cavia» al mejor artículo periodístico publicado en la prensa española. El 19 de julio de 1920, cinco días después del fallecimiento del escritor, Torcuato Luca de Tena, fundador y director del diario $A B C$, anunció la creación del concurso como homenaje a la obra del que fue «maestro de escritores» con la siguiente nota: «Para honrar la gloriosa memoria del maestro de escritores que cifró su cariño y sus entusiasmos en el ejercicio de la profesión periodística, $A B C$ instituye el premio "Mariano de Cavia" -consistente en 5000 pesetas-, que se adjudicará todos los años, empezando desde el actual [...]. $A B C$, con sincero espíritu de fraternidad, invita a todos los periodistas españoles a este concurso, para que el "Premio Mariano de Cavia" que 
abandono lo definiera certeramente Melchor Fernández Almagro (1958: 3) al afirmar el desapego mostrado por los historiadores de la literatura hacia el periodismo. La dificultad de acceder a una obra tan amplia y dispersa como la de Mariano de Cavia y, por supuesto, tan sujeta a la actualidad del momento ha provocado con toda seguridad el desinterés que comento, pero, como también señala Fernández Almagro, la cita con sus artículos es imprescindible para quienes tenemos como objeto de estudio la evolución de la prosa española durante los siglos XIX y XX.

Por otra parte, hay que advertir que frente a Azorín, Baroja, Unamuno, Maeztu o Ganivet, Mariano de Cavia es sólo periodista, es decir, durante más de cuarenta años se dedicó exclusivamente al periodismo: Nunca aceptó ni pretendió cargos públicos, la política le interesó sólo como ciudadano y comentarista, y su obra literaria se redujo a una pequeña colección de 16 cuentos (Cavia, 1897) escritos también para la prensa diaria y, según confiesa el propio autor en el prólogo, tan al correr de la pluma como cualquiera de sus «Chácharas», «Plato del día» o «Crónicas momentáneas», de completa actualidad.

Periodismo y literatura se aúnan en $\mathrm{Cavia}^{3}$, como más tarde en Julio Camba, en César González Ruano o en Francisco Umbral, por la calidad de su prosa, su estilo y su voz inconfundibles que, además, estuvieron en él unidos a una actitud ética coherente a lo largo de toda su vida. Y esta última circunstancia es muy importante para entender el papel social que representó el periodismo de Cavia, que le llevó a convertirse en uno de los articulistas con mayor influencia en la opinión pública española de su tiempo. Ejemplo claro y conocido de ello fue el escándalo organizado tras la publicación, el 25 de noviembre de 1891 en El Liberal, del artículo titulado «La catástrofe de anoche. España está de luto. Incendio del Museo del Prado» en el que Cavia utilizando la estructura de una crónica fingida ${ }^{4}$ avisaba de las peligrosas condiciones que

lleva en su nombre un excelso prestigio sea en lo presente y en lo futuro una consagración de méritos y un título de nobleza periodística».

3. En el Álbum de españoles ilustres de principios del siglo xx (1904), Cavia es considerado «como el más literato de todos los periodistas o el más periodista de todos los literatos». También Fernando Castán Palomar insiste una y otra vez en este maridaje, porque tratándose de un escritor que se dedicó exclusivamente al periodismo siempre fue considerado un literato: «Era toda una aspiración la de que el literato y el periodista fueran uno mismo [...] Y Mariano de Cavia hacía feliz realidad aquella ambición, porque él era periodista y escritor o escritor y periodista [...] Su literatura era eminentemente periodística, fundamentalmente periodística» (1956: 8 y 10).

4. Cavia da la noticia de un supuesto catastrófico incendio ocurrido durante la noche en el Museo del Prado. El artículo terminaba con un último párrafo aclaratorio en el que el periodista avisaba de que los sucesos reseñados podrían ocurrir el día menos pensado, 
padecía el Museo del Prado. La advertencia produjo tal revuelo general que el ministro del ramo, que era por entonces el señor Linares Rivas, no dudó en acelerar las soluciones necesarias para prevenir la peligrosa contingencia que el periodista denunciaba. Así lo comentaba el propio Cavia en el artículo publicado el 26 de noviembre de 1891, «Por qué he incendiado el museo de pinturas». Aquí reconocía el extraordinario efecto que su escrito provocó conmoviendo hondamente al pueblo de Madrid y las medidas inmediatas dictadas por el Ministro de Fomento para mejorar las condiciones del museo y así evitar la posible tragedia pronosticada por el periodista.

Son numerosísimas las causas públicas y privadas defendidas por el escritor desde las páginas de los periódicos a los que perteneciós. Con frecuencia las batallas llevadas a cabo con su pluma eran motivadas por alguna solicitud de sus lectores o recibían el beneplácito de los beneficiados, que dirigían directamente a Cavia su agradecimiento. En uno o en otro caso, las cartas publicadas en las páginas de los diarios manifiestan la cercanía y el contacto entre el periodista y sus lectores ${ }^{6}$. Estas campañas estaban avaladas por el

si no se llevaban a cabo las reformas necesarias en el famoso museo. Sin embargo, los lectores madrileños no esperaron a terminar la lectura del texto suponiendo como real lo que tan sólo era una advertencia.

5. Así, por ejemplo, en 1916 el Ayuntamiento de Madrid acordó dar a una calle madrileña el nombre de "Gustavo Adolfo Bécquer»; Cavia, conocedor de ello y sabedor de las estrechas relaciones entre el poeta y su hermano Valeriano y, sobre todo, del olvido sistemático que venía sufriendo el pintor, propuso en un artículo publicado en El Imparcial el 29 de febrero de 1916 que la calle llevara el nombre de «Los hermanos Bécquer». El Ayuntamiento aceptó la propuesta, y la iniciativa del periodista tuvo efectos positivos una vez más (Pageard, 1997: 299-300). Sin embargo, no siempre los resultados fueron favorables. Este es el caso de otra de las batallas sostenidas en contra de la decisión del Ayuntamiento de Zaragoza de demoler la Torre Nueva. Cuatro artículos publicados esta vez en El Liberal y dos meses, 12 de junio, 6 de julio, 23 de julio y 2 de agosto de 1892, no fueron suficientes para que Cavia consiguiera hacer anular la orden.

6. Los ejemplos que podría citar son muchos, pero comento sólo dos casos que confirman estos hechos. El viernes, 30 de agosto de 1918, aparece publicada en El Sol una carta que los vecinos de la calle de Sevilla envían a Mariano de Cavia agradeciéndole sus artículos a favor de la necesidad de un saneamiento físico y moral de la céntrica vía madrileña: «Madrid, 27 de agosto de 1918. Excmo Sr. D. Mariano de Cavia. Muy respetado señor nuestro: A la admiración que de antiguo le tributábamos se une en estos momentos un sentimiento de profunda gratitud por el inmenso beneficio que nos ha hecho al publicar en El Sol su notable artículo «Es mucha calle, señor, esa calle de Sevilla» [...] A usted se deberá esa obra de justicia por la que con tanto afán clamábamos; gracias a su acierto para exponer lo que sucede y al influjo de su prestigio para hacer decidir a la recalcitrante autoridad, la calle de Sevilla será al fin lugar libre de tránsito para el vecindario todo. Reciba usted, señor Cavia, la expresión de agradecimiento del comercio en ella establecido, a la que debiera unirse la del resto de los madrileños, porque a unos y a otros debe satisfacer la extirpación de esa plaga de vagos, vergüenza de la capital de España. Nos ofrecemos a usted afectísimos y agradecidos servidores, que estrechan su mano». 
influyente prestigio social que llegó a trascender las fronteras españolas ${ }^{7}$ y que había alcanzado a fuerza de mantener una actitud que no se doblegaba ante intereses económicos o políticos ${ }^{8}$. La labor periodística de Cavia se rigió siempre por unas normas deontológicas que el propio escritor defendió en diversas ocasiones. Así, en su prólogo al libro de Antonio Palomero, Trabajos forzados, señalaba la independencia como la característica más estimable del periodista: «(Palomero me) pide cuatro palabras previas que, forzoso me es decir, por no desairar a un compañero, que a sus méritos intelectuales, junta el que más estimo yo entre los profesionales: el de la independencia» (1898: XII). Y este comentario adquiere especial valor e importancia si tenemos en cuenta que está formulado en un momento en que el periodismo español es todavía fundamentalmente ideológico, dependiente de los partidos políticos, de los que se convierte en órgano portavoz. La profunda independencia de su labor periodística es precisamente lo más destacado por Miguel de Unamuno

En la misma línea, encontramos también en El Sol, el día 29 de noviembre de 1919, la reproducción de varios mensajes telegráficos enviados por un grupo de cigarreras de la Coruña, dos mil mujeres integradas en la Unión de las mujeres de Cataluña y por mil seiscientas federadas en la Federación Sindical de Obreras de Barcelona, felicitando a Cavia por sus artículos apoyando el feminismo y el derecho al voto de la mujeres españolas. Estos ejemplos muestran la cercanía de Cavia y sus lectores y la total actualidad de los temas tratados.

7. Sus gestos públicos llegaron a influir en los jóvenes periodistas y escritores de dentro y fuera de España. Cuando en 1918 El Sol sufrió el peso de la censura a causa de su clara postura aliadófila durante la primera guerra mundial, Cavia se negó rotundamente a seguir firmando sus artículos, mientras estos fueran mutilados por el censor correspondiente. Ante esta actitud, un grupo de periodistas portugueses manifestaron su apoyo a la decisión del ya famoso escritor por medio de un telegrama publicado en el periódico español el 28 de septiembre de 1918, pág. 3: «Lisboa 26,- Grupo de periodistas portugueses de la nueva generación tiene la honra de saludar al maestro Mariano de Cavia y manifestarle su simpatía y admiración por su notabilísimo gesto ante las violencias de la censura, que prometen no olvidar, como el más elevado ejemplo de pundonor moral y profesional».

8. El 19 de octubre de 1918, en la revista La Esfera, aparece un artículo, sin firma, titulado «De la vida que pasa. Galdós, Unamuno, Cavia» en el que se afirma de Cavia: «Es el gran satírico de nuestra época, el cotidiano censor - - oh! cómo se magnifica y engallardece esta palabra ahora que no suena en espíritus secundarios, ni se refugia en lápices anónimos- de la vida española. Reencarna en él, en su estilo castizo y cinglante, la burlona y terrible zumbonería de anteriores críticos y costumbristas. Desmigaja de la hoja volandera del periódico la masa prieta de la Historia. Hace hablar a los muertos para ejemplo o ludibrio de los vivos. Y siempre, incorregiblemente, sonríe. Esta sonrisa de Cavia es el penacho de su independencia. El airón que tiene derecho a ostentar por encima de sus compañeros de generación que desertaron buscando el pancismo. Tutea a los ministros, ex ministros, a otros menos afortunados en la logrería [...] Empezaron con él, e incapaces del espíritu de sacrificio ahora abren temblando el periódico temiendo que la pluma justiciera dibuje contornos ridículos a sus nombres».

Anales, 26, 2014, pp. 81-107 
en el artículo que le dedica en El Liberal, el 21 de julio de 1920, titulado «Una vida pública ejemplar»: «Lo más noble, lo más puro, lo más ejemplar de la vida de Cavia ha sido, en efecto, su admirable independencia de espíritu y de conducta. Independencia que a muchos parecería desdén y que acaso lo fuese. Nobilísimo, purísimo, ejemplarísimo desdén. Ni fue ni quiso ser nada más que periodista $»^{9}(1920: 1)$.

Además entendió el trabajo constante y la libertad como instrumentos para alcanzar la satisfacción de su espíritu. Así, al menos, queda expresado en las «tres eles» que para Cavia debían fundamentar el esfuerzo del profesional y que fueron recogidas en el Álbum de españoles ilustres de principios del siglo $X X$ ya citado:

....El de las tres eles: Labor, Libertas y Laetitia. Por el trabajo se puede lograr la libertad, y con la libertad se puede conseguir aquella sonriente visión de las cosas, necesaria de toda necesidad para que no se le resfríe a uno el espíritu con las humedades de este valle de lágrimas.

Con la bandera deontológica de la independencia para la expresión libre de ideas por medio del trabajo ${ }^{10}$, Mariano de Cavia se convierte en un escritor difícil de encasillar en grupos o ideologías demasiado definidos. Sin embargo, es obvio que ese mismo emblema conllevaba ya una actitud ideológica que no es complicada de delimitar. Es interesante observar cómo sus biógrafos, prologuistas o los muy escasos estudiosos de su obra periodística coinciden en señalar sus actitudes contradictorias, la ambigüedad de sus gustos, incluso la genialidad de su estilo, mezcla de lo castizo y lo novísimo, como afirma Ortega Munilla en el «prólogo» a la edición póstuma de las «Chácharas» (Cavia, 1923: 6), en una época, como ya sabemos, en que la defensa del casticismo o de la innovación significaba un enfrentamiento generacional importante. Ciertamente Mariano de Cavia es contradictorio por su misma independencia, pero también es evidente en sus artículos una actitud que podría calificar de manera general de «luchador contra las injusticias» desde la que vivió

9. Este artículo fue reproducido por El Sol el 22 de julio del mismo año.

10. Estos principios deontológicos se mantuvieron inalterables a lo largo de toda su carrera periodística. Los reconocemos claramente en el artículo programático que redactó para la presentación pública de El Sol el 1 de diciembre de 1917, cuando nuestro escritor llevaba ya más de treinta años de profesión: «Libres, absolutamente libres de clientelas y parentelas, taifas y pandillas de toda laya, compromisos de cofradía y ambiciones a costa del país, procuraremos ser los más modestos, pero los más leales y firmes servidores de la España que produce y trabaja, de la España que piensa y siente, de la España que tiene hambre de justicia, sed de cultura, derecho al bienestar ganado por los propios puños, de la España, en suma, que en sí misma y por sí misma ha de constituirse, despojándose de todos los oropeles de la España oficial y todos los guiñapos de la España de pandereta». 
los momentos de desaliento nacional. Sus inquietudes le llevaron a liderar o acompañar las protestas sociales o políticas allí donde surgieran, y con frecuencia esto sucedía en las redacciones de los periódicos ideológicamente más progresistas ${ }^{11}$. Y en ellos encontramos a Cavia.

Pero no sólo en su faceta profesional alcanzó una posición especial: en su vida privada también tendió a singularizarse. Frente al burgués de existencia apacible y monótona, el escritor mantuvo una postura excepcional e individualista, fuera de la mediocridad reinante y de los tradicionales valores morales. Dentro de sus contradicciones ya comentadas, destaca en lo personal una actitud aristocratizante, de distancia y desafío hacia los demás y, al mismo tiempo, una especie de anarquismo vital excéntrico: nunca tuvo propiedades ni pertenencias, vivió siempre en habitaciones de hoteles, acompañado tan sólo por un criado al que llamaba escudero ${ }^{12}$. Llevó una vida de excesos, nocturnidad y alcoholismo ${ }^{13}$ que no interrumpía, sin embargo, su trabajo diario en las páginas de los numerosos periódicos con los que colaboró. La peculiaridad de su comportamiento relaciona con naturalidad a Cavia con los grupos

11. Colaboró en 1897 en dos ocasiones en Germinal, en 1898 y 1899 publica en Vida Nueva y Revista Nueva, colabora desde 1890 hasta 1905 en Madrid Cómico, aunque también, siempre con su espíritu contradictorio, colabora esporádicamente en Gente vieja (Celma, 1991).

12. Mariano de Cavia tuvo dos escuderos a lo largo de toda su vida. El primero fue el llamado García, que había sido carlista y paje de D. Carlos durante la estancia de este en las provincias del norte. Después de fallecido García, ocupó su puesto Manso, que acompañó al periodista hasta la hora de su muerte. Ortega Munilla, en el prólogo a la edición póstuma de Chácharas, recuerda las palabras de Cavia acerca de su acierto en elegir edecanes: jamás tuvo que despedir ni separarse de ninguno (Cavia, 1923: 9-10).

13. Guillén Salaya (1953: 40) comenta haber visto a Mariano de Cavia beber aguardiente «en la cervecería "La Escocesa", sin tregua hasta el filo de la madrugada». También Cansinos Asséns (1982: 182-185), recuerda a Rubén Darío y Mariano de Cavia en una cervecería de la calle de las Hileras en Madrid, ambos muy borrachos. Rafael Cansinos se sorprende de que el poeta nicaragüense, hombre silencioso, tímido, afable pueda congeniar con el agresivo cronista y se pregunta « ¿Cómo Darío puede compaginar con ese hombre? El alcohol... Pero la borrachera de Rubén es taciturna, reconcentrada y decente, mientras que la del otro es vulgar y grotesca» (1982: 184). Felipe Sassone nos dejó también en sus memorias la imagen de un Cavia noctámbulo y bebedor: «todos los días, sin faltar uno, recalaba la barca de mis navegaciones nocturnas en el café de Fornos, donde me hice de nuevos amigos importantes. Allí conocí a don Mariano de Cavia, de quien admiraba el cacumen florido, la ilustración copiosa y la prosa impecable [...] No escribía en verso, al menos que yo sepa, don Mariano; pero bebía como un poeta que hubiese aprendido su latín y su castellano en Horacio y en Berceo, y una noche, al advertir que reiteraba con exceso las libaciones, hube de atajarle, respetuoso y amable: -¡Pero, por Dios, maestro!, ¿qué nos hemos propuesto? [...] Otras noches, porque el caso lo pedía, repetí la admonición, y él respondía siempre, humilde y medroso, como un niño castigado: -No me he propuesto nada, Sassone, nada malo. Ya ve ¡no bebo más!» (1958: 306-307).

Anales, 26, 2014, pp. 81-107 
de bohemios y modernistas que circulan por las noches madrileñas de fin de siglo, sin que por ello el periodista evitara criticarlos o menospreciarlos, si surgía la ocasión. De tal forma que no resulta extraordinario que, cuando el 10 de marzo de 1913, Ernesto Bark (1999: 306-307) publicó en El Radical de Madrid un manifiesto dirigido a «los poetas y poetisas de la vida», en el que formulaba una invitación abierta a los intelectuales no burgueses a formar parte del cenáculo de bohemios cuyo lema era «Arte, Verdad y Libertad $»^{14}$, contara con Mariano de Cavia entre sus miembros. Según informa el folleto de Bark ${ }^{15}$ «los verdaderos leaders de la Bohemia española serían, además de las sombras de Alejandro Sawa, Manolo Paso y Rafael Delorme, los poetas inspirados Joaquín Dicenta, Emilio Carrère, Edmundo González Blanco, Mariano de Cavia, Villaespesa y el admirable Antonio Palomero» (1999: 31). Desde París completarían el elenco Luis Bonafoux y Emilio Bobadilla.

Así encontramos a Mariano de Cavia con sus casi 58 años apoyando lo que Bark denominaba «el nuevo foco de idealidad y romanticismo», sin que ello le impidiera llamar «cretinos» a algunos modernistas, como menciona Cansinos (1982: 185), o defender, en una de sus famosas series de artículos, «Limpia y fija», el purismo lingüístico hasta el punto de llegar a convertirse, según Julio Casares (1918: 121), en un «casticista a todo trapo ${ }^{16}$. En ninguno de estos

14. El plan para organizar ágapes mensuales y dar cohesión y presencia a la variada tribu bohemia de la ciudad había sido elaborado algunos años antes por Ernesto Bark junto con Alejandro Sawa, pero desafortunadamente la ceguera y la muerte prematura del escritor habían frustrado el primer intento.

15. En efecto, Bark recoge en su folleto el suelto con el que la prensa reseñó el acontecimiento: "Anteanoche se reunieron los bohemios, cuya bandera es Arte, Verdad y Libertad, en el café Mercantil, y después de un animado cambio de impresiones, fue aceptado un proyecto de editorial cooperativa para facilitar la publicación de libros con el apoyo de los aficionados de letras, por obligaciones, desde cinco pesetas, reembolsables por la venta del libro respectivo o ejemplares del mismo con el 50 por ciento de rebaja. El proyecto presentado por varios pintores de ayudar la venta de cuadros, fue aceptado en principio, y su discusión definitiva aplazada hasta el próximo viernes, que tendrá lugar la segunda reunión del Cenáculo. Además de la discusión de los asuntos de actualidad, con exclusión absoluta de la política, se analizarán las obras recién publicadas de Albornoz, Bonafoux y Ramírez Ángel, Ideario Radical, Los españoles en París y Beethoven. Las adhesiones al Cenáculo y la suscripción a la publicación de libros de la editorial cooperativa, diríjanse a la redacción de Economía Social, Libertad, 6» (1999: 30-31).

16. Su preocupación por la lengua española y su enorme e importante labor periodística le llevó a ser elegido por unanimidad académico de la lengua en la Junta Ordinaria celebrada por la Real Academia el 24 de febrero de 1916 para ocupar el sillón A, en el que le había precedido Menéndez Pidal: «En la junta académica ordinaria del 3 de febrero se dio lectura a la propuesta hecha a favor de don Mariano de Cavia para cubrir la vacante de individuo de número causada por el fallecimiento de don Juan Menéndez Pidal. Y, transcurrido el término reglamentario, en la sesión del 24 del mismo mes, 
aspectos fue totalitario: es cierto, por una parte, que criticó el modernismo, pues huyó siempre de normas, escuelas y tendencias:

¿Y qué es el modernismo?...El modernismo es el arcaísmo vuelto del revés. Eso cuando acierta. Y cuando no, lo antiguo reflejándose en lo nuevo... El modernista, como el cultiparlante de los anocheceres puesto en solfa por Quevedo, pretende descubrir nuevos horizontes, o como dice él, soles nuevos, y con efecto, todas las mañanas descubre uno... que se había puesto la tarde anterior... Otras veces el modernismo se reduce -icasos de trapería sublimada!- a lo viejo indígena pasado por agua, o a lo viejo exótico pasado a cuchillo. De esto último hay ejemplos criminales. De lo otro ejemplos candorosos, en donde la buena fe del modernista se complica con el falso asombro del snob... (Cavia, 1901b: 1).

Sin embargo, también es cierto que nunca dejó de demostrar su profunda admiración por los grandes poetas modernistas. El propio Rubén Darío reconoce que el conocido periodista «no ha sido hostil, como otros, para los nuevos poetas; pero sí ha sido y es implacable para los poetas malos, nuevos y viejos» (1950: 604). El sentimiento por la muerte de Darío, el más importante de los defensores del modernismo, le inspiró un bello responso con palabras exaltadísimas de veneración y respeto. Porque, en realidad, Cavia, lo único que rechazaba del modernismo, como de cualquier otro movimiento estético, era la imitación servil y la falta de genio. Por eso al hablar del poeta nicaragüense dice:

Así como en los triunfos de los Césares y caudillos romanos no faltaba el voceador de improperios, a fin de que los vítores no desvaneciesen al triunfador, tampoco faltará en el glorioso cuanto abigarrado séquito de Rubén Darío la ralea servil de sus imitadores, de estos que no han sabido imitarle más que en sus licencias caprichosas, en sus escapatorias a la turbia región de la extravagancia, sin acertar iluminar la imitación simiesca con un solo rayo de aquel numen que hoy, depurado por el Dolor y por la Muerte, entra en definitiva y soberana esfera de la Gloria [...] Tus hados, oh inolvidable amigo de toda mi amistad, oh poeta digno de haber logrado mayor y más serena fortuna en esta vida, han dispuesto que entrases en la región de los tuyos como entraron los padres de Hamlet y Falstaff, de Don Quijote y Sancho: con el tumultuoso cortejo, ya sublime, ya prosaico, que acompaña a todas las grandezas y todas las flaquezas de esta Humanidad que ha tenido en ti admirable, envidiada, divertida y dolorida representación.

Siendo muy hombre, te acercaste a los dioses. Ellos darán a tu sombra y a tu fama la paz inmarcesible que no lograron tu espíritu y tu cuerpo en sus

quedó elegido, por unanimidad, académico de número el referido ilustre literato don Mariano de Cavia» (Boletín de la Real Academia Española, 1916: 137). Aunque, según Ortega Munilla (Cavia, 1923: 6), Cavia anhelaba el momento de la recepción, no llegó a pronunciar el discurso de ingreso, sucediéndole Adolfo Bonilla y San Martín. 
turbulentas andanzas por este valle donde una vislumbre de gusto y risa se paga con un raudal de lágrimas y penas. (Cavia, 1916, pág. 1).

Precisamente por su eclecticismo, su iconoclastia y su individualismo esencial no resulta sorprendente verlo incluido en el cenáculo bohemio de Bark; de la misma forma que estas características lo relacionan también con la generación que comenzó a formarse hacia 1885, un núcleo precursor que se autodenominaba «gente nueva» y de la que, como señala Allen Phillips (1999: 14), surgió cronológicamente la primera oleada de bohemios españoles: Luis Bonafoux, Silverio Lanza, Luis Paris, Alejandro Sawa, Antonio Palomero, Ricardo Fuente y otros nombres menos conocidos. Fue éste un grupo «puente» de simpatías progresistas, de inquietudes sociales contestatarias, culto y con buen conocimiento de las lenguas y las literaturas extranjeras, cualidades todas que identifican y adornan a Cavia ${ }^{17}$. A todos sus miembros, como a Cavia, el momento de transición de las letras españolas que les tocó en suerte compartir les hace parecer un grupo contradictorio e incoherente, sin embargo su presencia nos permite entender mejor la evolución hacia la crisis de fin de siglo y la revolución modernista. En este mismo orden de cosas, Luis Ruiz Contreras (1961: 357-358) justifica el olvido, salvo algunas excepciones, de casi todos sus miembros por el hecho de que constituyan el enlace entre dos generaciones potentes y brillantes, como fueron la del realismo y la del modernismo:

17. Luis Araujo-Costa (1952: 193-194) sitúa a Cavia como figura importante en el ambiente finisecular de la plaza madrileña apuntando cada uno de los rasgos que acabamos de señalar: "Cavia conoce a la perfección a los clásicos y los cita con oportunidad y gracia singulares. Es hablista de gran empuje y a diario en las columnas de El Imparcial da una lección de tauromaquia, de gastronomía, de lenguaje castizo, de literatura, de historia, de sano españolismo. Tiene Cavia acentuado parentesco con Quevedo y escribe una prosa fluida y con músculo a lo Cervantes. Conoce la dipsomanía, desde el «vaso de bon vino» de Gonzalo de Berceo, hasta el «Embriagaos» de Baudelaire, y en sus tertulias de la Puerta del Sol, al lado de García y con su habitual muletilla "ehum, ehum", comenta lo divino y lo humano, poniendo a prueba su saber portentoso, su buen sentido, su condición de español, que no ignora las lenguas principales, las obras escritas y el modo de decir y hacer que se emplea en las naciones más renombradas de Europa». También Rubén Darío (1950: 601) resalta su vasta cultura y su conocimiento de las lenguas extranjeras: "Aunque en él no haya nada improvisado, a pesar de las exigencias del periódico, porque bien nutrido como está, bien pertrechado en toda suerte de disciplinas, siempre encuentra para toda circunstancia la anécdota aplicable, la cita precisa, el recuerdo a propósito, el refrán irreemplazable, el verso o la frase en castellano o en cualquier idioma vivo o muerto. El inglés, el francés, el italiano, el portugués los conoce perfectamente. En cuanto al latín no sé si lo conoce, pero sí que, como Sarmiento, si no sabe latín, sabe latines». 
Ser joven indica, en arte, vivir ignorado. Por esto la duración del periodo juvenil tiene alternativas. Las generaciones intelectuales se producen, por ejemplo, cada diez años, y la fuerza del hombre dura 20 o 30 años. De manera que las generaciones inmediatas a un gran movimiento intelectual tiene una juventud larga; es decir, no vencen jamás. En cambio, la situación halla fácil el triunfo; la brecha está iniciada, y el combatiente, fatigado. Se dice que después de una generación triunfadora viene otra raquítica, y no es verdad. Lo que ocurre, sin duda, es que después de una generación triunfadora la siguiente halla un obstáculo poderoso. Hace treinta y tantos años que se fraguó la última revolución, origen del estado actual. Muchos de aquellos hombres aún viven; hasta hoy conservaron el poder: la política, el periodismo, el teatro, todo era suyo. ¿Cómo luchar contra unas fuerzas - unas verdaderas fuerzas- organizadas, independientes, atrincheradas? Por eso las generaciones del 80 y del 90 (cuento por decenas para mayor sencillez) ofrecieron poco fruto. No siendo peores que los hombres de la Revolución, llegaban a mala hora, y casi todos perecieron en la oscuridad. Pudo salvarse alguno aisladamente, pero no pudo producirse un movimiento intelectual. No hacía falta. Y aun los que se salvaron demuestran lo que digo, porque no consiguieron todo lo que merecían. Cito un solo ejemplo: Mariano de Cavia. Mucho es, mucho se le quiere, mucho se le respeta. Pero ¿a qué no hubiera llegado apareciendo algunos años antes?

\section{Mariano de Cavia en El Liberal}

Según Lacadena Brualla (1955: 16-18), Castán Palomar (1956: 36-37) y Faci Ballabriga (2010: 49-50), fue el actor Rafael Calvo ${ }^{18}$, quien convenció a Cavia para que se trasladara a Madrid desde su Zaragoza natal. No se conoce con seguridad el año de llegada del periodista. Al parecer, y siempre según los autores citados y el artículo de El Sol del 15 de julio de 1920, el joven escritor traía una carta de presentación del jurisconsulto aragonés Joaquín Gil Berges, antiguo ministro de la República, para Eleuterio Maisonnave, director de El Globo. Sin embargo, todo parece indicar que la carta no llegó nunca a su destino. Lo cierto es que el primer periódico para el que comenzó a trabajar en Madrid fue El Liberal, siendo su director Luis Polanco hasta que en 1882 lo sustituyese en la dirección Mariano Araús Pérez. Enrique Pardo Canalís

18. Parece que Calvo se encontraba en Zaragoza actuando en el Teatro Principal. Ni Ramón Lacadena ni Fernando Castán ni Mariano Faci señalan cómo o dónde obtienen la información, aunque todos coinciden con los datos ofrecidos en el artículo publicado sin firma en la pág. 2 de El Sol, el 15 de julio de 1920, titulado «Cavia: sus aficiones, sus luchas, sus campañas y sus triunfos. (Apuntes para una biografía)». Sin embargo, el artículo del periódico da como fecha del inicio de la amistad entre Calvo y Cavia el año 1879, mientras que Castán Palomar afirma que fue en 1881. Ramón Lacadena no da fecha.

Anales, 26, 2014, pp. 81-107 
(Cavia, 1980: 13) asegura que Cavia ingresó en El Liberal hacia 1880; sin embargo, lo único que puede afirmarse con total seguridad es que la primera vez que apareció su firma en este periódico, concretamente en el suplemento literario «Entre páginas», dirigido por Isidoro Fernández Flores (Fernanflor), fue el 23 de enero de 1881. Se trata de un artículo titulado «La lectura de Núñez de Arce», donde Cavia reseña la presentación que del poema Hernán el Lobo había hecho su autor la noche anterior en el Ateneo madrileño (Faci, 2010: 50).

Cavia permanece en El Liberal hasta 1895 con una única interrupción, al parecer de pocos meses. Según un artículo sin firma publicado en $A B C$ el 16 de julio de 1920 titulado «Cavia en Barcelona», en 1881, el conde de Ríus, personaje político notable de la provincia de Tarragona, fundó un periódico titulado Diario Democrático, de Tarragona, órgano del partido democrático progresista. El primer número del periódico apareció el 8 de junio de 1881 y Mariano de Cavia llegó de Madrid para dirigirlo hasta el mes de noviembre del mismo año, en que se separó por desavenencias con los propietarios ${ }^{19}$.

En Madrid, de nuevo, vuelve a incorporarse a El Liberal, hasta que el 21 de agosto de 1895 Heraldo de Madrid anuncia el ingreso en sus filas de nuestro periodista en los siguientes términos ${ }^{20}$ :

La redacción del Heraldo de Madrid experimenta un placer vivísimo al comunicar a los lectores del periódico dos noticias que seguramente recibirán todos ellos con verdadera satisfacción. La primera es que el ilustre escritor Mariano de Cavia, a quien circunstancias especiales han movido a separarse de El Liberal, está desde hoy en nuestra compañía. Rotos sus compromisos con aquel diario, nos hemos apresurado a solicitar su concurso, deseosos de que en adelante no tuvieran nuestros lectores que envidiar a los de ningún

19. Fernando Castán Palomar (1956: 51-52), Faci Ballabriga (2010: 51) y el artículo de El Sol del 15 de julio de 1920, ya citado, afirman además que fue el conocido periodista Julio Vargas Machuca, redactor de El Liberal, quien recomendó el nombre de Mariano de Cavia como director del periódico catalán. No he logrado contrastar esta información. Sí puedo afirmar que El Diario de Tarragona, en sus ediciones de los días 7 de junio y 6 de noviembre de 1881, ofrece, respectivamente, las noticias de la llegada de Mariano de Cavia a la ciudad para hacerse cargo de la dirección de El Diario Democrático, que saldría a la calle por primera vez el 8 de junio, y del cese de su dirección, que se hizo efectivo a partir del jueves, 3 de noviembre.

20. María Angulo (Cavia, 2008a: 41-42) cita un artículo aparecido en el núm. 39 de la revista Actualidades del 11 de noviembre de 1908, en el que se explica que el motivo de la salida de Cavia de El Liberal en 1895 fue la publicación del artículo titulado «Adoración a las Santísimas llagas de Cánovas Nuestro Señor» dentro de la serie «Plato del día». María Angulo sospecha que la crítica de Cavia al tipo de oposición que Francisco Silvela estaba haciendo al líder de su propio partido, Cánovas del Castillo, pudiera no haber gustado a los directores del matutino. 
otro periódico los frutos de este cultísimo y peregrino ingenio, cuyo nombre es tan popular en España. Mariano de Cavia ha respondido cariñosamente a nuestro llamamiento, y está ya con nosotros...

Sin embargo, la satisfacción de los lectores de Heraldo de Madrid duró poco, porque el 15 de diciembre de 1895 El Imparcial, en su segunda página, anuncia la inminente incorporación en sus filas de Mariano de Cavia, cuyo primer artículo se publicará el 24 de diciembre del mismo año ${ }^{21}$ :

Mariano de Cavia, el ingenioso y culto escritor con cuya valiosísima colaboración se honraban Los Lunes de EL Imparcial tendrá en lo sucesivo más frecuente y activa participación en la labor de este periódico, tomando a su cargo las crónicas teatrales y otros trabajos de carácter exclusivamente literario. Con verdadera satisfacción, porque estimamos en todo su valor el mérito de escritor tan ilustre, damos esta agradable noticia a los lectores de El Imparcial.

Continuó en este último periódico hasta que, en 1917, una vez constituido el «trust» formado por El Liberal, El Imparcial y Heraldo de Madrid, pasa, con la mayoría de los periodistas de El Imparcial, a El Sol, donde permanecerá hasta su muerte en 1920.

Además colaboró esporádicamente en casi todos los periódicos madrileños: La Ilustración Española y Americana, Madrid Cómico, La Caricatura, Germinal, Vida Nueva, Revista Nueva, Gente Vieja ${ }^{22}$, La Lidia ${ }^{23}$, Nuevo Mundo ${ }^{24}$, La Correspondencia Musical ${ }^{25}$, por citar sólo los que he podido consultar ${ }^{26}$.

$\mathrm{Su}$ ya mencionada larga permanencia en El Liberal tuvo como consecuencia un abundantísimo número de artículos sueltos, así como varias cabeceras fijas que se mantuvieron durante años. Entre ellas, habría que destacar sus

21. En las páginas literarias de este periódico, Los Lunes de El Imparcial, la firma de Cavia venía apareciendo con asiduidad desde el 14 de octubre de 1895 en el que publicó el artículo titulado «El ateo en Misa».

22. Pilar Celma (1991) hace un vaciado muy detallado de todas las colaboraciones de Cavia en estos periódicos.

23. Cavia colabora en esta revista de toros durante la segunda época de la publicación en la que se convierte en una «Revista semanal ilustrada» de «arte-literatura-sport». Comienza su colaboración el 25 de abril de 1894 con la cabecera fija «Coche parado. (Crónicas al aire libre)». La serie se mantiene hasta septiembre, aunque continúa escribiendo para la revista con artículos sueltos al menos hasta 1900, último año que he podido consultar completo.

24. Colabora durante el año 1912 con la serie de artículos titulada «De usted para mí».

25. Aquí colaboró desde el 27 de agosto hasta el 24 de noviembre de 1885 con una serie titulada «Músicos aragoneses». Se trataba de repasar la historia de la música en Aragón y de rendir homenaje a los más ilustres músicos aragoneses ya desaparecidos.

26. Pardo Canalís (1980: 14) cita también sus colaboraciones en otros periódicos como El Burladero y Madrid Crema, que no he podido encontrar, o La Risa, La Opinión, La Lucha y La Justicia.

Anales, 26, 2014, pp. 81-107 
«Crónicas momentáneas» que se publicaron desde el 26 de noviembre de 1890 hasta el 13 de febrero de 1895. Asimismo fue en El Liberal donde comenzó la serie "Chácharas» que se haría popular un poco más tarde, cuando el periodista ya pertenecía a la redacción de El Imparcial. La primera «Cháchara» que he encontrado se fecha el 27 de octubre de 1894 y se mantendrá hasta que Cavia abandone el periódico. Sin embargo, y sin lugar a dudas, las más importantes de este periodo fueron las cabeceras «Plato del día» $\mathrm{y}$ «Desde la barrera. Notas de Sobaquillo». Prueba evidente de su popularidad es la larga duración de ambas, 9 años la primera, que analizaremos a continuación, y 14 la segunda, desde el 10 de abril de 1882 hasta el 29 de octubre de 1894, así como su importante influencia social ${ }^{27}$.

En esta ocasión, y a causa de los límites de espacio, me centraré en el análisis de la primera de estas dos cabeceras, especialmente significativa en relación con la prosa y las preocupaciones temáticas de su autor ${ }^{28}$.

\section{Plato del día}

El primer artículo de la serie «Plato del día» se publica en El Liberal el 25 de febrero de 1886. La cabecera se mantiene durante nueve años, hasta el 8 de abril de $1895^{29}$. No presenta una periodicidad fija, lo más frecuente es que aparezca entre dos y tres veces a la semana, y la extensión también es variable. A partir del 24 de mayo de 1888, todos los artículos llevan títulos, lo que resulta una novedad, pues hasta esa fecha solo cuatro textos habían sido titulados (28 de diciembre de 1887, 24 de enero, 12 de marzo y 21 de abril de 1888).

Es obvio que, en una serie tan larga en el tiempo y tan abundante en artículos, más de 550, la variedad temática y las estrategias estilísticas son múltiples. En el año 1891, por tanto cuatro años antes de que desapareciera la serie, fueron coleccionados en el libro titulado Azotes y galeras (Cavia, 2008a) 38 artículos que pertenecen a la primera etapa de la cabecera y que son un

27. Pardo Canalís (1980: 16) da cuenta de esta popularidad al reseñar una obra de teatro titulada Plato del día «Extravagancia lírica en un acto y dos cuadros original y en verso», de Ruesga, Lastra y Prieto, con música del maestro Miguel Marqués, estrenada en el madrileño teatro de la Alhambra el 20 de abril de 1889, con dedicatoria a Mariano de Cavia.

28. El que presento aquí es el avance de un estudio más detallado que publicaré próximamente.

29. Contamos con una edición facsimilar de la cabecera completa que facilita, por supuesto, el acceso a los textos (Cavia, 2008b). Citaré siempre por esta edición detallando la fecha del artículo y la página en la que se encuentra. 
buen ejemplo de la complejidad temática y técnica que acabo de señalar ${ }^{30}$. En el prólogo del recopilatorio, fechado en agosto de 1890, Cavia expresa bien la índole de la mayor parte de sus «Platos del día» publicados hasta esta fecha: «de los cuales diría que andaban por ahí descarriados, y quizá sin el nombre de su dueño, si no fuera irreverencia citar palabras de Cervantes a propósito de cosas tan flojas y baladíes como las que se contienen en estas páginas» (2008: 101). Más allá de la captatio benevolentiae que se reconoce con facilidad en el párrafo citado, encontramos destacada por el propio autor una característica que sí es evidente en los artículos que corresponden a la década de los años 80: el perfil de los temas tratados. Si bien es excesivo calificarlos de flojos o baladíes, es cierto que muchos de ellos tratan asuntos curiosos, raros y de variedades, como el propio Cavia afirma en el «Plato del día» del 18 de febrero de 1888 , p. 85 : «No; no tema usted que vaya hablarle de la crisis agraria, ni de la decadencia del Carnaval, ni de la hecatombe de Río Tinto, ni de la Patti y sus pasos de agilidad, ni de Castelar y sus tropezones del mismo género, ni siquiera de la cuestión Orléans, Bourbon, Hapsbourg, and Company (Limited)».

Efectivamente, no suelen ser estos los temas de sus artículos. Por el contrario, el periodista prefiere comentar a sus lectores las costumbres de las élites y las particularidades de las monarquías europeas, los extraños inventos que dice haber encontrado en la prensa parisina, como el antífono o los fonogramas, la lengua silbada de los habitantes de la isla de la Gomera, «los únicos españoles que están en disposición de hablar del gobierno como se merece» (31 de mayo de 1888, p. 94), la angloparlomanía que se ha apoderado de nuestros comerciantes e industriales, los «sobres bomba» que han puesto de moda en Europa los fenianos, los nihilistas y los anarquistas y que empiezan a extenderse como moda chic también en España... y un amplio número de asuntos extravagantes que por obra y gracia de su ingenio adquieren la gravedad que le otorga entidad al texto.

El punto de partida de los artículos puede ser muy diverso: un comentario oído al azar, una carta recibida de alguno de sus lectores proponiéndole determinada cuestión, cualquier prospecto caído en sus manos y sobre todo

30. En el año 1901 apareció un breve folleto titulado Grageas (Cavia, 1901a), donde se recogen seis artículos de la serie «Plato del día» de los cuales cuatro ya habían sido recopilados en Azotes y galeras. Son los que llevan por título «Historia de un brillante», « ¡Ni en Chicago!», «Equipos de invierno»y «Cúbranse ustedes». Los otros dos artículos que completan la selección: «¡Aquellos tiempos!» y «Poisson d'Avril», no habían sido recogidos en libro. Lo curioso es que «Grajea» (sic) será el título de una nueva cabecera que inaugurará en El Imparcial al año siguiente de la publicación de este folleto, concretamente el 8 de julio de 1902. 
las noticias extraídas de los periódicos nacionales: «Este de hoy no es de casa de Lhardy ni de Pécastaing. Nos lo proporciona La Correspondencia» (25 de febrero de 1886, p. 340) e internacionales: «como ahora viene todo de Viena, no he podido leer sin un estremecimiento cierta noticia que viene de los periódicos de allá» (1 de marzo de 1888, p. 86), que repasaba cada día. A veces es el mismo El Liberal el que le ofrece la noticia a comentar: «El Liberal habló ayer del estreno en Martín de una obra exclusivamente destinada a anunciar un licor» (6 febrero 1889, p. 104). A partir de aquí elabora un artículo de opinión cuya argumentación rara vez es lógica, antes bien suele basarse en una hipótesis propia. Ésta se desarrolla por medio de una especulación que adquiere valor en sí misma sin necesidad de fundamento racional. Así, por ejemplo, partiendo de la pregunta «¿Podemos los fieles confesarnos por teléfono?» que asegura haber recibido de uno de sus lectores y haber hallado al mismo tiempo en periódicos de Roma y de París (18 de marzo de 1888, p. 88), el articulista responde con ironía: «No puede darse en estos tiempos una cuestión más seria, más ardua ni más trascendental...-Ante ella, pierden toda su importancia la crisis agraria, la crisis económica, la crisis política, la crisis social, y demás pequeñeces de la vida moderna». Desde aquí comienza a hilar casos ingeniosos e hipotéticos en los que la confesión telefónica sería muy útil, pero también muy poco seria, para llegar al final del texto sin dar solución alguna al asunto. La verdad es que la solución no interesa, porque el acento se ha puesto en la argumentación ingeniosa y en su desarrollo especulativo. Por eso termina con una simple exclamación que le lleva, eso sí, a un aspecto que ya he mencionado en Cavia y que es tan importante como su firma: el sentido crítico que encontramos en todos sus escritos: «iHay tanta filoxera en la viña del señor!».

La ironía y el sentido crítico hacen que la especulación y el ingenio adquieran una finalidad que trasciende la sencilla anécdota, punto de partida del artículo. De esta forma, Mariano de Cavia encaja a la perfección en la definición que William Thackeray hace del escritor humorista: «es el que despierta y dirige nuestro espíritu, nuestra compasión por los débiles, nuestro desdén por la mentira y por la hipocresía, nuestra misericordia por los pobres, por los oprimidos, por los desgraciados» (en Arrarás, 1948: 10; y Larkin \& Figueroa-Dorrego, 2002: 177). Nadie como Cavia para ascender la nimiedad a la categoría de crítica social, sin perder en ningún momento el buen talante con el que se sitúa frente a su texto. Así ocurre en el artículo titulado «Equipos de invierno» (5 de octubre de 1889, p. 116). La base de la reflexión es la llegada a manos del periodista de un catálogo de modas de una casa de París dedicada exclusivamente a vestir perros. Por supuesto que Cavia da un repaso 
minucioso a los modelitos caninos para la temporada otoño-invierno, pero sin dejar de intercalar entre párrafos llenos de frivolidad y humor comentarios personales sobre el agravio que esto supone para la pobre gente que no tiene con qué protegerse del frío: «Deléitense, pues, con esas noticias [...] las infelices madres que están sin saber qué poner a sus hijos para combatir las inclemencias del tiempo, y consuélense pensando que no andará el mundo tan mal arreglado que hasta los perros tienen ya a su disposición cómodos y abrigados batines para ir por casa». Con esta afirmación el articulista deja bien centrada, por una parte, su valoración del tema y, por otra, el recurso a la ironía que transforma un artículo de asunto aparentemente ligero, en un texto de crítica social que ilumina su finalidad periodística.

Ahora bien, dentro de la gran variedad temática, podemos detectar en esta cabecera una línea de evolución que lentamente va decantándose hacia la política, llegando a convertirse ésta en el tema central de sus artículos.

Cavia no es un comentarista político propiamente dicho. Sus afirmaciones no son casi nunca argumentadas con razonamientos lógicos. Entra en el asunto de forma tangencial, no hay teoría política ni análisis de situaciones y mucho menos propuestas de solución, sólo se ofrece la crítica a la clase política sin desarrollar específicamente, sobreentendiendo que sus lectores compartirán esa crítica y comprenderán sin más aclaración el sentido de sus comentarios.

La política y los políticos no son para Cavia nada más que motivos de burla e ironía y no de argumentación ideológica; el desarrollo argumentativo de una tesis sobre una información política dada supondría otorgarle un estatus de seriedad a un país que sobrevive de milagro: «¡Como que hasta las catástrofes resultan en él verdaderos beneficios de la Providencia, afortunadamente! Confiemos en ella; y dejemos a otros pueblos la virtud de la previsión. Afortunadamente, no ha pasado para nosotros todavía la época de los milagros. Y de eso vivimos, afortunadamente» (24 de marzo de 1893, p. 232).

Desde luego, es obvio que los lectores de Cavia no buscan ni la profundización ni el análisis, sino la degradación de asuntos de mayor gravedad que quedan desacreditados al pasar por el tamiz de la pluma del periodista. Ahora bien, esta degradación subrayada por la ironía supone una valoración amarga y pesimista del asunto tratado y es ahí donde aparece la perspectiva más o menos deliberativa de Cavia, convirtiendo al final su crítica en un ejercicio persuasivo que busca la adhesión de su público con fórmulas poco recomendadas por la lógica.

La estructura formal de sus escritos políticos es muy variada, rasgo, por otra parte, muy comprensible si tenemos en cuenta la cantidad de textos con 
los que trabajamos. Con todo, puedo afirmar que la mayoría pertenece a la categoría de artículo expositivo-especulativo en el que la argumentación no responde a una exigencia lógica, sino que parte de unas hipótesis que no necesitan fundamento racional ${ }^{31}$. Son muchos los artículos que muestran estas referencias: En el titulado «La gran mojiganga» (1 de julio de 1889, p. 109) compara la corrida de toros celebrada en París por los españoles el «Gordo», el «Gallo» y el «Lagartija», que aceptaron «estoquear» con un plumero toros embolados, con el espectáculo diario del Parlamento español. Cavia afirma: «Ante la gran mojiganga parlamentaria de Madrid, pierde todo su jocoso interés la gran mojiganga taurina de París». A partir de aquí dedica el artículo a criticar y burlarse de los políticos españoles de todas las facciones. De cabestros ejercen los disidentes liberales «que han perdido a manos de los conservadores los atributos más importantes de su virilidad política». A Cánovas lo compara con el «Gordo», porque «trae aparejada "la gorda" siempre que torea». Hasta la verdadera minoría opositora, cercana al pensamiento de Cavia, sale caricaturizada en esta burla: «hasta picadores de pura apariencia tenemos acá. Los honorables individuos de las minorías republicanas. Hombres fornidos, de recia musculatura, expertos en la pelea, buenos jinetes y armados de temibles garrochas, hacen lucidamente el paseo, ganan palmas, y después... se quedan entre barreras».

El 8 de abril de 1895 (pp. 337-338), El Liberal publica en primera página el «Plato del día» titulado «Adoración a las santísimas llagas de Cánovas Nuestro Señor, por un silvelista arrepentido» que ilustra a la perfección la estrategia comentada. Cavia utiliza aquí la fórmula de una plegaria en la que un seguidor de Silvela pide perdón a Cánovas por haberlo supuestamente ofendido:

«A la de la mano derecha». Adórote, Santísima Llaga, y os doy, Señor, por ella las gracias. Por ella y por el dolor que os ocasionó al abrirse, cuando tuvisteis que negar la diestra a vuestro amadísimo y predilecto discípulo Romero Robledo, con motivo de su fuga al reformismo después de la «crisis del espanto», así como por el dolor que os causó al enconarse, cuando más tarde tuvisteis que estrechar con la propia mano la de Bosch y Fustegueras, con motivo de haberos librado indirectamente de los leales que a con tamaña abnegación os soportaban: Os pido una verdadera contrición de mis culpas, y que me perdonéis cuanto os he ofendido, pensando como pensé en tiempos que nunca transigiríais con los romeristas que tan malamente os

31. Teodoro León Gross (1996:181) define el artículo expositivo-especulativo como aquel discurso que no se basa en información ya conocida, sino que «plantea hipótesis interpretativas más o menos verosímiles y argumenta sobre un referente de la actualidad a partir no de la información sino de esas premisas». 
abandonaron, y creyendo luego que nunca pospondríais la necesidad de una justa y severa «selección» higiénica a los impulsos de esa vuestra bondad archidivina que supera la del mismísimo Jesús de Nazareth para con la pecadora María de Magdala.

Con una obvia intención irónica, critica la «incoherencia política» de Cánovas del Castillo que pacta con amigos y enemigos de las distintas facciones del partido conservador, no habiendo otro motivo que intereses políticos muy personales. Es un texto en el que la lógica estricta es sustituida por giros ingeniosos que estableciendo analogías absolutamente dispares consigue dar a entender lo contrario de lo que parece expresar. No parte de un hecho informativo, que se comenta y argumenta, sino de unas opiniones propias sobre un referente de actualidad como es la trayectoria política del líder del partido conservador, cuyo poder absoluto identifica Cavia con el poder supremo y religioso de un «Nuestro Señor» ofendido por los supuestos adversarios de su misma filosofía política. El motivo de la petición de perdón por parte de uno de esos adversarios («un silvelista arrepentido»), que adopta el papel de narrador, y que no podemos identificar con el autor, que se presenta en la firma final como intermediario ( «por la incorrección de pruebas, Mariano de Cavia»), complica aún más la estructura del texto. Si autor y narrador no coinciden, la base del artículo de opinión queda rota en un juego ficcional de aserciones que, por el marco en el que aparecen, simulan la no ficción. La misma fórmula de la plegaria pone en duda, en un principio, la verosimilitud propia del artículo periodístico, pero dicha verosimilitud se reafirma de nuevo en la licencia de la ironía que vuelve seriamente contra Cánovas las peticiones del silvelista utilizado por Cavia para expresar sus propias ideas. La técnica empleada es más literaria que periodística, ya que el referente informativo queda relegado al juego de asociaciones sorprendentes y caprichosas que como señala Francisco Umbral: «es la gran cualidad poética del ensayista» (1994: 260).

La estrategia de las analogías ingeniosas tiene siempre una utilidad crítica. Cualquier artículo, por muy anecdótico que parezca, conecta en algún momento con el sistema de la Restauración y el enjuiciamiento de sus políticos ineptos desde todo punto de vista y sea cual sea su ideología: Así en el «Plato del día» titulado «El Mesías de ahora» (12 de diciembre de 1893, p. 264), el tema es el de un nuevo Mesías que viene de Boston y que profetiza el caos del mundo. Todo el artículo es un divertido alegato sobre la Teosofía y las sociedades teosóficas, hasta que de improviso, al final del texto, Cavia se las compone para entremeter el tema de la política española: 
Foulke anunció hace algunos meses (y esto es lo grave, lo siniestro, lo que le ha dado allende el Océano, inmensa autoridad), que el incendio, la borrasca, la conflagración empezarían en Europa... por EsPAÑA. En rigor, no se necesita ser muy Mesías para anunciarnos eso. Basta con saber que gobierna Sagasta o Cánovas para asegurarnos toda clase de calamidades.

Junto al uso de las comparaciones sorprendentes, otras características confluyen para dotar al estilo de Cavia del sello personal que le es propio en esta cabecera. Una de las más frecuentes es la que se refiere, como ya he señalado, al modo en que nuestro periodista suele entrar en el asunto que comenta. Normalmente lo hace de forma tangencial, es decir, parece importarle más la anécdota que la esencia del tema que trata, porque rara vez lo aborda desde el mismo meollo de la cuestión. De esta manera ocurre en el artículo publicado el 7 de junio de 1893 (p. 233), titulado « ¡Sacacuartos!»:

Me parece que estoy llamando al perro. Porque yo tuve en tiempos un perro -no en calderilla, sino de Terranova-que se llamaba Sacacuartos, y hubiera servido para ministro de Hacienda lo mismo que cualquier otro.

$-i$ Lo mismo que cualquier otro perro?

- ¡No señor; lo mismo que cualquier otro ministro!

Sacacuartos (que ya «pasó a mejor vida» como pasará Gamazo y pasarán tantos otros hacendistas), estaba enseñado como ninguno de sus congéneres, tanto en lo canino como en lo financiero.

Volvemos a encontrar que el comienzo del texto se basa, como es frecuente, en una analogía anecdótica y curiosa: el nombre del supuesto perro del periodista se relaciona con la labor del Ministro de Hacienda, para llegar de forma tan contingente al verdadero asunto del artículo: la crítica al ejercicio económico de dicho ministro, Sr. Gamazo. El tema central no suele ser enfrentado frontalmente, sino por el costado de la minucia sobre la que luego el periodista hará surgir el mundo ingenioso de sus propias ideas:

¡Perros y arbitristas!... Cervantes los emparejó ya en su maravilloso «Diálogo» de Escipión y Berganza, y no hay mayor prueba de genio que ésta que nos ofrecen los hacendistas de ogaño; la de hacer posibles, probables y realizables hasta los delirios de los redentores y salvadores que le salían a la Hacienda española trescientos setenta y tantos años há. Aquéllos decían: -Con que ayunen durante un día todos los españoles, y dejen para el Tesoro todo lo que habían de gastar en su comida y bebida, sale de apuros el erario. Los de ahora nada dicen, pero hacen mucho. No ya por un día, ipor toda una eternidad dejan a España entera en ayunas!...

¿Ahorrar? Nada.

¿Sacar? Todo.

Así ocurre que se nos echa encima el periodo de las vacas flacas (estilo bíblico, para uso de Carullas... y otros aficionados a verlas venir). Y así hay gallegos-sin cartera-que piensan en hacerse ingleses. Y hay navarros-sin 
Rodrigo-que tratan de irse con el francés. Y hay muchísimos españoles más que optamos por hacernos...el sueco.

Nuestro jefe en este cambio de nacionalidad, o en esta finis Hispania, es el Sr. Gamazo.

Pero cuando Cavia llega a lo sustancial no permanece en ello olvidando la anécdota, sino que lo circunstancial gira alrededor de lo esencial en un círculo dentro del cual los temas se entrelazan. Así el final del texto une los dos referentes creando una forma geométrica perfectamente cerrada en la moraleja y con la firma de Mariano de Cavia:

A su sistema se atiene el insigne hacendista, y no hay quien le aparte de él. Se cifra y se compendia en este principio: «Para sacar los cuartos al país... ¡hacerle cuartos!». Mi perro no llegaba ahí. Era de Terranova; no de presa. Mariano de Cavia.

Cavia se burla de la clase política española en general criticando el sistema de la Restauración incapacitado, según el periodista, para solucionar no sólo los grandes sino incluso los más insignificantes problemas políticos y sociales de España. Ningún aspecto de la política española ni de la jerarquía política queda libre de su pluma ácida y crítica: presidente, cancilleres, senadores, concejales y, cómo no, alcaldes, principalmente el de Madrid. Los ejemplos son continuos, el 21 de enero de 1895 (p. 328-329) comenta significativamente:

¡Y se tacha todavía a nuestros ediles de gente corta en las ideas, manca en la iniciativa y torpe en la acción!... Don Julián Romea, el gran actor, solía decir: -Los que no hacen comedias, ¿qué harán? Y así pregunto yo también: -Los cronistas que por esos mundos no tengan a mano Ayuntamientos como el de Madrid, ¿de qué escribirán? ¿con qué entretendrán a sus lectores? ¿cómo llenarán las columnas de sus periódicos? Bendigamos el inagotable y fecundo manantial de la Casa de la Villa, que aunque a las veces se desborden sus aguas poco limpias, hasta el légamo que dejan sirve para fertilizar más y más nuestro natural ingenio [...] Bendigamos, sí, el légamo extensísimo de la concejalería, gracias al cual podemos escribir acerca de algo que no sea la fuga de Perier y la elección de Fauré, las tarifas de ferrocarriles y la crisis agraria, la nube-Gamazo y el pedrisco-Moret.

Una nueva estrategia estilística utilizada con frecuencia en los artículos expositivo-especulativos de «Plato del día» es la del interrogatorio y del diálogo fingidos puestos en boca de personajes reales del mundo de la actualidad o de tipos generales no identificados individualmente. Ejemplo del primer caso es el artículo titulado «¿Qué opina usted de la retirada de Guerrita?» (7 de julio de 1994$)^{32}$.

32. Este artículo no aparece recogido en la edición facsimilar de «Los platos del día» (2008b). Por esto cito directamente del periódico, pp. 1-2. 
Como todavía se hallan de moda los interrogatorios acerca de los sucesos y novedades de excepcional interés, y como el anuncio de la retirada de Rafael Guerra constituye la novedad «sensacional» del día, no hemos querido -siguiendo nuestra costumbre en ocasiones análogas-dejar a nuestros lectores sin saber cómo opinan acerca de tan grave e inesperado suceso algunas de las personalidades más salientes, y aun de las más entrantes, de este ameno y regocijado país.

Las respuestas, inventadas por Cavia, simulan estar firmadas, entre otros, por Sagasta, Cánovas, Núñez de Arce, «Sobaquillo», Campoamor, Romero Robledo, Silvela, Grilo, Lagartijo, Peña y Goñi, Castelar, Moret y Frascuelo. Algunas, sobre todo las que están firmadas por los políticos, son utilizadas para criticar su hedonismo, incoherencia y deslealtad política. Así Sagasta dice: « ¡Retírase en la flor de la edad, de las facultades y de las simpatías! Eso es lo mismo que si yo, por dar gusto a mis enemigos, abandonase ahora la política para siempre, en la flor de las simpatías, de las facultades y de la edad». Romero Robledo y Silvela contestan al unísono: «¿Se corta, efectivamente, la coleta Rafael II? ¡Bah! También me la corté yo en clase de canovista, y con Cánovas he de volver a torear». Para Cánovas, cuyo estilo literario conoce bien Cavia, elabora una respuesta larga, enrevesada, con un verbo barroco, pero vacío de contenido, para terminar ofreciendo a Guerra un puesto en el partido conservador:

Se cae y se da en la cuenta, como es forzoso dar y caer, de que bien puede mudarse por mejorarse y bien puede hacer dejación de aquellas regias y codiciadas insignias quien logra y recaba fortuna harto más apetecible, cual es la de dedicarse a mi servicio y ponerse a la sombra benéfica de mis banderas y pendones; porque otras cosas tendrán derecho a decir la crítica histórica y la exégesis taurina, mas no a dejar de reconocer, según es de ley y de razón que así lo reconozcan, cómo el denodado estoqueador andaluz, al poner en pie de ejecución su resolución definitiva, ingresa de hecho y derecho en el partido conservador, y conquistando en él puesto y lugar de merecida y alta preferencia.

Las respuestas de los poetas aparecen imitando sus estilos personales: Campoamor: «Humorada: No sé si me divierte o si me aterra// ver en guerra a la paz y en paz al Guerra». Núñez de Arce: «¡Oh adornos! ¡Oh mónadas! ¡Oh alegrías// de los pasados días!// ¡Oh gallardos alardes de grandeza!//¡Oh luz! ¡Oh sol! ¡Oh gracia! ¡Oh gentileza!// ¡Oh infundios! ¡Oh folías!». Y para terminar con los ejemplos, unos cuantos versos al estilo de Grilo: «Hay en la verde sierra// sobre las lomas// unas casitas blancas// como palomas.// Y allá en el llano...// fincas que rentan mucho,// y eso es lo sano».

Más frecuente es el segundo caso mencionado, es decir, encontrar diálogos ficticios en los que los intervinientes no son identificados de forma 
individual, sino con fórmulas generales, como, por ejemplo: «Dos fusionistas indecisos se repasan mutuamente la lección del día de mañana» («Geografía política», 8 de marzo de 1895, pp. 334-335). A menudo los diálogos son muy breves y se intercalan en el estilo indirecto del narrador para aligerar la prosa o también para ofrecer la información noticiosa de la forma más breve y rápida posible: « ¿Y ese nuevo Mesías, como se llama? -Enrique Foulke. ¿De dónde viene? -De América. ¿A dónde va? -A la cárcel, probablemente; según suele acontecer a todos los redentores de profesión». («Plato del día», 12 de diciembre de1893, p. 264). A veces son palabras fingidas puestas en boca del personaje o personajes sobre los que se comentan algún hecho, como, por ejemplo, la identificación entre el alcalde de Madrid, señor Santiago Angulo, y el sultán de Marruecos, Muley Hassán, ( «Dos grandes caracteres contemporáneos. Dos vidas paralelas. El mejor Muley, Angulo. El mejor Angulo, Hassán», 18 de febrero de1894, pp. 276-277):

-A mí que no me hablen (dice Muley Hassán) de derecho público, de política internacional, de leyes profanas... Yo no conozco ni obedezco más prescripciones que el Korán. A mi Mahoma me atengo, y el que lo quiera que lo tome, y el que no, que lo deje.

No se expresa de otro modo el señor Angulo.

-A mí que no me hablen (dice) de ley municipal, ni de representantes del pueblo, ni de reclamaciones de la opinión, ni de necesidades de población, ni de deberes de partido... Yo no conozco más que la real orden que me hizo alcalde. A mi vara me atengo, y el que lo quiera que lo tome, y el que no, que lo deje.

Muchas de las técnicas de sus estrategias ingeniosas se ponen de manifiesto en el «Plato del día» del 4 de julio de 1890 (p. 149) titulado «La política en 1891» en el que, utilizando un «médium vidente», Cavia adelanta algunas primicias políticas del año 1891. La visión del futuro afirma la continuidad del presente que es lo que el periodista asegura con cada uno de los desastres políticos y sociales que va confirmando: Castelar y Ruiz Zorrilla en el exilio de París, las Universidades cerradas, Cánovas poderosísimo y férreo, el carlismo en auge, los militares alemanes en España agregados a cada una de la capitanías generales, las elecciones manipuladas, Silvela separado una vez más de Cánovas... y de esta manera seguirá enumerando los temas que arruinarán un año más y, por tanto, un poco más la salud política de este país. El nuevo año visionado propicia la burla, que no tiene en absoluto base argumentativa lógica, aunque en realidad tampoco la necesita para que el público lector pueda entender como probables todos los vaticinios del «médium» del autor sobre hechos que deducimos como verosímiles o normales, dada la trayectoria política del país y el quehacer de sus políticos. 
No todos los textos de «Plato del Día» son expositivo-especulativos. A veces, aunque pocas, sucede en el mundo de la actualidad algún hecho que merece el respeto de nuestro periodista. En esas circunstancias abandona la burla y la especulación para dar paso a la información, la argumentación lógica y la valoración positiva del suceso noticioso. Así, por ejemplo, ocurre en el artículo titulado « ¡Coronas de duque!... iA real, a real la pieza!» publicado el 22 de enero de1895 (pp. 329-330):

Es el grito callejero, después de haber sido el grito parlamentario. Es el pregón del día de hoy, después de haber sido el escándalo de la sesión de ayer [...] Lo que a la Nación importa e interesa, puesto que ante ella se discute la cuestión consabida, es llegar a la deducción lógica e inevitable que se desprende de un estado de cosas, acerca del cual ha dicho el mismo conde de Xiquena, según lo que han repetido muchos periódicos: -Si la «grandeza de España» se puede lograr por ciertos medios y con ella la posesión vinculada del cargo de legislador, vale más suprimir las senadurías por derecho propio [...]

Hecha trizas la dejó ayer el conde de Xiquena, con sus crudísimas revelaciones y con la tumultuosa muchedumbre de consecuencias que de ella nacen; pero aun en este holocausto a la claridad -nada común en la actual época del trampantojo y el tapujo-muestra don Joaquín Álvarez de Toledo su desinterés caballeresco, su franqueza a la antigua española, y su fidelidad al viejo lema: «Prius mori quam foedari».

Para atacar el derecho a las senadurías por derecho propio, bástales a sus adversarios recoger el puñal que briosamente les arrojó ayer el conde de Xiquena desde los muros de Tarifa [...] Pero y esta es la cuestión que interesa a todos, cualesquiera que sean sus ideas acerca de coronas, mantos y cetros, ¿es igualmente evidente e indispensable la necesidad del «privilegio personal y hereditario de legislar» de las senadurías por derecho propio, en un país regido por leyes liberales y democráticas, a título o a pretexto de representar a la Corona misma en la alta Cámara?

Bastante representada en las Cortes está ya la Corona por sus prerrogativas, por el Gobierno de su confianza y por los partidos monárquicos...Y esto no lo digo yo: lo dicen monárquicos y aristócratas bien cabales en la muy monárquica y muy aristocrática, pero también muy liberal Inglaterra, en donde sin que nadie se alarme, sin que nadie se escandalice, sin que siquiera ocurran cosas como las que el conde de Xiquena ha tenido el valor de descubrir, se pide a diario en la prensa, en las reuniones públicas, y hasta en la Cámara popular, no ya la anulación de aquel privilegio, sino la supresión de la misma Cámara de los Lores.

Si la vergonzosa gravedad del asunto, si las serias consecuencias que los partidos democráticos están obligados a sacar de él, si en tal colada no anduviera por medio el honor de gobernantes y funcionarios que son o han sido, y si la valerosa y severa actitud del conde de Xiquena, no fueran circunstancias que declaran inoportuno cierto género de cuchufletas, yo me atrevería a 
decir-tan escasas y tristes son mis esperanzas-que el señor conde pudo haber empezado su tremenda oración con la conocida coplilla de Sueños de Oro:

Sus prometí un concierto,

y sus le tengo a dar,

aunque todo esto sea...

música celestial.

Este artículo entra en la categoría de los que podríamos llamar textos descriptivo-valorativos $^{33}$. En primer lugar, el autor informa sobre una serie de acontecimientos ocurridos el día anterior en el parlamento acerca de la denuncia del conde de Xiquena sobre los títulos de nobleza obtenidos por medios fraudulentos. La información ofrecida es valorada y argumentada en relación con la importancia que este hecho tiene para las senadurías por derecho propio de las que disfrutan, como representantes de la monarquía, la aristocracia española. En este caso, Cavia elabora una argumentación de desarrollo lógico mediante la cual el artículo discurre en secuencias de afirmaciones que mantienen entre sí una relación causa-efecto perfectamente razonable.

El texto es especialmente interesante porque en él aparecen otras de las características propias del periodismo de Cavia. Por un lado, encontramos las citas en latín, que el autor manejó siempre con inmensa soltura y abundancia, junto a citas en francés e inglés, que son frecuentísimas en sus artículos: ya comenté más arriba el conocimiento de lenguas de Mariano de Cavia. Es este un rasgo de cosmopolitismo que se une al conocimiento de la vida política y social de otros países gracias a la consulta diaria de periódicos extranjeros que constituía, según comenta el propio autor, uno de sus primeros entretenimientos matutinos. Nuestro periodista nunca salió de España, por tanto sus conocimientos sobre las lenguas y la cultura de los países europeos provienen de sus lecturas de textos escritos y de la prensa exterior. En esta ocasión, es Inglaterra el país que le sirve de comparación en el tema de la existencia de unos privilegios senatoriales que el autor argumenta como innecesarios y cuya supresión «se pide a diario en la prensa inglesa», sin que ello sea motivo de escándalo, llegando incluso, como declara, a solicitarse la supresión de la Cámara de los Lores.

Por último, y tras el alarde de una elevada cultura cosmopolita, Cavia termina el artículo mostrando también su conocimiento de la cultura popular, otro rasgo que se repetirá a lo largo de su trayectoria periodística. Ahora

33. Teodoro León Gross (1996: 181) lo describe como aquel «discurso que presenta una cantidad variable de información sobre un referente noticioso (ya sea hecho, personaje u otro motivo) y que a partir de esa selección de información permite acometer una valoración de ese referente, siendo esta valoración el objetivo último del artículo». 
se manifiesta en la cita de una coplilla que le sirve de afirmación final para mostrar su escepticismo sobre el hecho de lograr alguna solución en relación a cualquier desaguisado en la política española.

Estas son, en definitiva, las características temáticas, formales y argumentativas de la serie «Plato del día». Comienza siendo una miscelánea de temas variados y anecdóticos para terminar convirtiéndose en una crítica irónica de todo el sistema de la Restauración. Mediante analogías sorprendentes, diálogos fingidos, argumentos especulativos e ingeniosos, entrevistas inventadas, personajes-narradores y citas eruditas o populares, Cavia pone en solfa la labor de los políticos más importantes de la época, burlándose con ironía de la corrupción e ineptitud de los dos partidos turnantes. Conservadores y liberales son en esta serie nada más que las dos caras de una misma moneda cada vez más desprestigiada y la única que acabará circulando en un país que nuestro periodista consideraba arruinado a causa de una vida política y económica absolutamente inservible.

Por otro lado, la compleja y variada retórica argumentativa de los artículos y el uso de la ironía, el humor y la cultura para acentuar la crítica política y social nos permiten comprender mejor el proceso de evolución de la prosa periodística española hacia un modelo de concisión persuasiva, precisión en el vocablo y fluidez comunicativa que anuncia, a finales del siglo XIX, las nuevas formas del periodismo moderno.

\section{«Bibliografía citada»}

Álbum de españoles ilustres de principios del siglo XX, Madrid, Blanco y Negro, XXXIX, (1904).

Araujo-Costa, Luis, Hombres y cosas de la Puerta del Sol, Madrid, Editora Nacional, 1952.

ARRARÁS, Joaquín, «Fernández Flórez: el periodista, el novelista y el hombre de humor», Cuadernos de literatura, III, 7, (1948), pp. 3-14.

BARK, Ernesto, La Santa bohemia y otros artículos, ed. Gonzalo Santoja, Madrid, Celeste ediciones. Biblioteca de la bohemia, 1999.

Boletín de la Real Academia Española, Madrid, III (1916).

CANSINOS-AsSÉNS, Rafael, La novela de un literato. (Hombres-Ideas-EfeméridesAnécdotas), 1, (1882-1914), Madrid, Alianza, 1982.

CASARES, Julio, Crítica efimera (divertimentos filológicos), Madrid, Calleja, 1918.

Castán Palomar, Fernando, Cavia, el poligrafo castizo, Pamplona, Editorial Gómez, 1956.

CAVIA, Mariano de, Cuentos de guerrilla, Barcelona, Librería Española, 1897.

— «Responso pagano», El Imparcial, 10 de febrero de 1916. 
- Grageas, Madrid, Imprenta de Antonio Marzo, 1901a.

— «Libertad, libertad sacrosanta», El Imparcial, 18 de agosto de 1901b.

- Chácharas, prol. José Ortega Munilla, Madrid, Renacimiento, 1923.

- Antología, ed. Enrique Pardo Canalís, Zaragoza, Diputación, 1980.

- [1891], Azotes y galeras, ed. María Angulo Egea y M. ${ }^{a}$ del Rosario Leal Bonmati, Asociación de la prensa de Aragón, 2008a.

- Platos del día, Madrid, Hemeroteca Municipal, 2008b.

Celma Valero, Pilar, Literatura y periodismo en las Revistas de fin de siglo. Estudio e indices (1888-1907), Barcelona, Júcar, 1991.

DARío, Rubén, «Mariano de Cavia», Obras completas, Tomo I, Crítica y ensayo, Madrid, Afrodisio Aguado, 1950, pp. 598-606.

FaCi Ballabriga, Mariano A., Mariano de Cávia y Lac, periodista zaragozano, Zaragoza, Institución «Fernando el Católico», Diputación Provincial, 2010.

Fernández Almagro, Melchor, «Mariano de Cavia», ABC, 11 de abril de 1958.

Guillén SAlAYA, Francisco, Los que nacimos con el siglo. Biografía de una juventud, Madrid, Colenda, 1953.

LACADENA BRUalla, Ramón, En el primer centenario del nacimiento de Mariano de Cavia y Lac, Zaragoza, Librería General, 1955.

LARKIN GALIÑANES, Cristina y J. Figueroa-Dorrego, «El concepto de humor en escritores ingleses del siglo XIX y escritores gallegos del XX», Babel AFIAL, número extraordinario (2002), pp. 171-194; <http://webs.uvigo.es/angelestome/ concepto_humor.pdf> [consulta: 30 marzo 2014].

LEÓN GROSS, Teodoro, El artículo de opinión, Barcelona, Ariel, 1996.

PAGEARD, Robert, «Mariano de Cavia y la calle de los hermanos Bécquer», El Gnomo, 6 (1997), pp. 299-300.

PALOMERO, Antonio, Trabajos forzados, pról. Mariano de Cavia, Madrid, Librería de Fernando Fé, 1898.

PHiLLiPS, Allen W., En torno a la bohemia madrileña. 1890-1925. Testimonios, personajes y obras, Madrid, Celeste ediciones. Biblioteca de la bohemia, 1999.

Ruiz Contreras, Luis, Memorias de un desmemoriado, Madrid, Aguilar, 1961.

SASSONE, Felipe, La rueda de mi fortuna (memorias), Madrid, Aguilar, 1958.

UMBRAL, Francisco, Las palabras de la tribu, Barcelona, Planeta, 1994.

UnAmUno, Miguel: «Una vida pública ejemplar», El Liberal, 21 de julio de 1920, p. 1 / El Sol, 22 de julio 1920, p. 2.

Fecha de recepción: 08/04/2014

Fecha de aceptación: 01/09/2014 